\title{
Removal of doxycycline hydrochloride from aqueous solution by rice husk ash using response surface methodology and disposability study
}

\author{
Gurleenjot Kaur $^{1} \cdot$ Neetu Singh ${ }^{2}$ (1) $\cdot$ Anita Rajor ${ }^{1} \cdot$ Raj Kumar Arya $^{3}$
}

Received: 3 September 2021 / Accepted: 26 January 2022 / Published online: 14 February 2022

(c) The Author(s), under exclusive licence to Springer-Verlag GmbH Germany, part of Springer Nature 2022

\begin{abstract}
The huge demand and consumption of DOX, its incomplete metabolism, and complex behavior in atmosphere are causing a great ecological issue, which needs to be solved. In the present study, the suitability of rice husk ash (RHA) for the greater sorption efficiency of DOX antibiotic was investigated. Furthermore, disposability study of exhausted RHA was performed using solidification technique and leachate had undergone toxicity test to evaluate the DOX encapsulation ability. The central composite design under RSM was employed for the design of experiment and optimization of adsorption parameters. RHA was characterized using various techniques such as XRD, SEM (EDX), FTIR, BET, and zeta potential analysis. The influence of various adsorption parameters, like initial DOX concentration $\left(C_{0}\right)$, RHA dosage $(m)$, incubation-time period $(t)$, and $\mathrm{pH}$ were examined on the performance in terms of DOX elimination $\%\left(\mathrm{X}_{1}\right)$ and adsorptive capacity $(\mathrm{mg} / \mathrm{g})\left(\mathrm{X}_{2}\right)$. At optimized conditions, the obtained $X_{1}$ and $X_{2}$ were $98.85 \%$ and $17.74 \mathrm{mg} / \mathrm{g}$, respectively. Moreover, the kinetics data suited well to the pseudo-second-order model. Freundlich, Langmuir, and Redlich-Peterson (R-P) isotherm models were applied, out of which Langmuir model best performed under optimized conditions; $m=5 \mathrm{~g} / \mathrm{L}, t=85.85 \mathrm{~min}$, DOX concentration $=89.73 \mathrm{mg} / \mathrm{L}$, and $\mathrm{pH}=6$. The bacterial toxicity test of leachate confirmed complete encapsulation of DOX by solidification technique.
\end{abstract}

Keywords Rice husk Ash · Doxycycline hydrochloride · Adsorption isotherms · Diffusivity studies · Solidification and stabilization

\section{Introduction}

Pharmaceutically active compounds (PACs) and their complex metabolite forms are present in the $\mathrm{H}_{2} \mathrm{O}$ cycle of the

Responsible Editor: Tito Roberto Cadaval Jr

Neetu Singh

neetu.singh1479@gmail.com

Gurleenjot Kaur

gurleenswaich22@gmail.com

Anita Rajor

arajor@thapar.edu

Raj Kumar Arya

aryark@nitj.ac.in

1 School of Energy and Environment, Thapar Institute of Engineering and Technology, Patiala 147004, India

2 Department of Chemical Engineering, Thapar Institute of Engineering and Technology, Patiala 147004, India

3 Department of Chemical Engineering, Dr. B.R. Ambedkar National Institute of Technology, Jalandhar, India environment. It is extensively identified all over the globe, and the concentrations of PACs are examined in the ground and potable water specimen. These compounds fall into the emerging chemical class due to their significant consumption, broad reactivity, health hazards, and ecological risks (Sobsey and Bartram 2002). Antibiotics are classified in several categories like fluoroquinolones, trimethoprim, sulfonamides, and tetracyclines. Out of these, tetracyclines (TCs) are one of the highest consumed antibiotics for controlling various diseases due to their effective results (Saygili and Guzel 2016). Presently, antibiotics have been detected in influents and effluents of wastewater streams and almost $50-90 \%$ is in the form of metabolites (Li et al. 2013). Where, TCs were widely identified antibiotic $(\approx 80 \%)$ in the industrial and domestic drainage systems. Doxycycline hydrochloride (DOX) is an antibiotic that belongs to the tetracycline 
(TC) group (Kaur et al. 2021c). Due to its wide-ranging antibacterial function and effectiveness on gram-positive and gram-negative strain of bacteria, it has achieved more popularity than other TC antibiotics ( $\mathrm{Li}$ et al. 2013).

Recently, DOX has been used with other drugs to minimize COVID-19-induced inflammation (Gupta and Rana 2020). Due to the complicated physicochemical behavior of DOX, it shows complex nature in the ecosystem. In proportion to its complicated structure and good solubility, DOX exhibits high residual toxicity in the aquatic environment. Due to the high solubility of DOX in water, it contaminates the water bodies and increases antimicrobial resistance of microorganisms (Kaur et al. 2021b). There is a need to find the suitable process for the removal of DOX present in the wastewater. Numerous processes (physical, chemical, biological, and advanced oxidation) have been employed for the elimination of DOX from wastewater. Due to energyintensive nature and formation of toxic intermediates, most of these processes do not find its industrial application (Kaur et al. 2019a, b; Rani et al. 2021). On the other hand, adsorption is an operative technique at a large scale and is away from these drawbacks (Kaur et al. 2021d).

Few researchers have come out with the sorption of TCs with the help of different types of adsorbents like montmorillonite (Zhao et al. 2012), carbon nanotubes (Kim et al. 2014; Tang et al. 2014), graphene (Gao et al. 2012), mesoporous silica (Zhang et al. 2015), $\mathrm{Fe}_{3} \mathrm{O}_{4}$ (Ghaemi and Absalan 2015), and sea buckthorn biocarbon (Zhang et al. 2016). Most of them are associated with drawbacks like high cost, regeneration inability, and poor adsorption capacity. Very few adsorbents have been explored which provide efficient removal rate and good sorption capacity. On the other hand agri-residues are better options for adsorption of antibiotics due to their abundance availability, negligible cost, and good performance.

In the present study, RHA was selected as sorbent for the uptake of DOX from its aqueous solution. Rice husk is one of the highest produced agricultural waste materials that contains about 22-25.5\% of their weight (Mohamed et al. 2015). It is used as fuel materials into the incinerators by various industries and the ash produced is called RHA. The worldwide rice husk production is approximately 545 million metric tons, whereas India alone generates approximately 18-22 million tons of rice husk annually (Srivastava et al. 2006). Therefore, huge amount of rice husk burnt or deposited as wastage creates various environmental and health-related problems (Kaur et al. 2021a; Naiya et al. 2009). So, there is a need to utilize this ash generated from incinerators. Moreover, because of a very high silica content (more than $80 \%$ ), RHA has the exceptional ability to be used as an adsorbent. Due to its noble physical and chemical characteristics, many researchers have used RHA for the removal of various pharmaceutical compounds. Earlier, ofloxacin hydrochloride, paracetamol (Thakur et al. 2020), ofloxacin (Kaur et al. 2021a), oxytetracycline (Andrade et al. 2020), and pyridine (Lataye et al. 2008) were adsorbed on RHA with high removal capacity.

The central objectives of this research study are as follows: (1) to measure the degree of removal of DOX using RHA as adsorbent (2) optimization of process parameters using RSM and evaluation of suitable kinetic and isotherm models (3) solidification/stabilization of exhausted RHA and bacterial toxicity analysis of leachate to evaluate the degree of encapsulation of DOX.

\section{Experimental}

\section{Materials and characterization techniques}

The RHA was purchased from the rural market of Patiala, India. It was cleaned using hot water and undergone drying for overnight at $70{ }^{\circ} \mathrm{C}$ temperature. After drying, it was screened, and the used particle size of RHA was $180-600 \mu \mathrm{m}$. Now, it was used as an adsorbent without any further treatment. The doxycycline hydrochloride (DOX) with chemical formula $\mathrm{C}_{22} \mathrm{H}_{25} \mathrm{ClN}_{2} \mathrm{O}_{8}$ and molecular weight $480.9 \mathrm{~g} / \mathrm{mol}$ was obtained from Varav biogenesis Private Ltd. Himachal Pradesh, India.

The wastewater of DOX antibiotic was synthetically prepared in different concentrations, using deionized water. All the chemicals employed for this work were of analytical class. For maintaining the desired $\mathrm{pH}$ of DOX solution, 1-2 $\mathrm{N} \mathrm{H}_{2} \mathrm{SO}_{4}$ and $\mathrm{NaOH}$ solutions were used. The spectrophotometric analysis of DOX solutions was performed at $345 \mathrm{~nm}$ wavelength, using UV-VIS spectrophotometer (model HITACHI U-2000). A Thomas Scientific incubator shaker was used for adsorption studies.

\section{Rice husk ash characterization}

Various characterization techniques were used to evaluate the morphological and chemical properties of RHA. The specific surface area was evaluated with the help of BET technique, and the pore volume (total) was evaluated at a relative pressure of about 0.95 in the presence of liquid nitrogen. The pore size was determined via Barrett-Joyner-Halenda (BJH) technique. The morphology of the activated carbon was inspected via scanning electron microscope and elemental composition has been obtained by EDX analysis (Hitachi S4800 HR-SEM, Germany).

The XRD (X-ray diffraction) pattern of RHA was evaluated by Bruker D8-Advance X-ray diffractometer (Bruker, Germany), at $2 \theta=10-90^{\circ}$ with $\mathrm{Cu}$ as the object and $\mathrm{Ni}$ as the filter media with $\lambda=1.541 \AA$ having K $\alpha$ radiations. It shows the specific interactions between the adsorbate and adsorbent. Moreover, the FTIR pattern was obtained with 
the help of a spectrophotometer (Nicolet 6700 spectrometer, USA) amid $4000-400 \mathrm{~cm}^{-1}$ wavelength range at room temperature which represents different functional groups on the RHA surface before and after adsorption.

The point of zero charge $\left(\mathrm{pH}_{\mathrm{Pzc}}\right)$ of the RHA was also evaluated, which facilitated in understanding the sorption mechanism of DOX on the RHA surface. Salt addition technique was used for this purpose. In this method, the deviation between the zeta potential values was estimated, and the point at which $\Delta \mathrm{pH}$ becomes nil was measured as $\mathrm{pH}_{\mathrm{Pzc}}$ of RHA. The $\mathrm{pH}_{\mathrm{Pzc}}$ of RHA was determined by following the similar procedure reported earlier (Mahmood et al., 2011). For this purpose, eleven clean conical flasks of $100 \mathrm{~mL}$ capacity were taken and $40 \mathrm{~mL}$ of $0.1 \mathrm{M} \mathrm{KCl}$ solution was poured into each flask. The solution $\mathrm{pH}$ of different flasks were adjusted to different values ranging from 2 to 12 with the help of $0.1 \mathrm{M} \mathrm{H}_{2} \mathrm{SO} 4$ and $0.1 \mathrm{M} \mathrm{NaOH}$ as per requirement. Furthermore, $0.2 \mathrm{~g}$ of RHA sample was added into each flask and these flasks were placed in a rotary shaker for $24 \mathrm{~h}$ at room temperature and $200 \mathrm{rpm}$. After $24 \mathrm{~h}$, the supernatant of each flask was taken out and its $\mathrm{pH}$ was measured. The difference between the initial and final $\mathrm{pH}$ was evaluated, and the point at which difference $(\Delta \mathrm{pH})$ is zero was considered as pHpzc of RHA. The $\mathrm{pH}_{\mathrm{Pzc}}$ of RHA was evaluated as 8.1 and is shown in Fig. S1.

\section{Experimental design and optimization of parameters}

The sets of experiments for DOX adsorption on RHA were designed by applying Design-Expert software version 13 (DX10). Full factorial design was used based on two levels with 8 axial points and 6 center points. The CCD model involves four varying parameters (initial concentration, time, $\mathrm{pH}$, and adsorbent dose) whereas temperature and rotation speed remain constant throughout the experimentation. The ranges were setup like the following: DOX concentration (10 to $90 \mathrm{mg} / \mathrm{L}$ ), adsorption duration (10 to $750 \mathrm{~min}$ ), $\mathrm{pH}(2-10)$, and dosage of RHA $(0.5-2.5 \mathrm{~g} / 100 \mathrm{~mL})$. Variables were coded with five different levels of CCD model (Table 1). These were observed as self-reliant sorption parameters, whereas $\left(\mathrm{X}_{1}\right)$ and $\left(\mathrm{X}_{2}\right)$ were designated as responses. The quadratic model was used to fit the experimental findings, analysis, and optimization of adsorption parameters as given by Eq. (1).

$X=\psi_{0}+\sum_{i=1}^{k} \psi_{i} x_{i}+\sum_{i=1}^{k} \psi_{i i} x_{i}^{2}+\sum \sum_{i<j} \psi_{i j} x_{i} x_{j}+D_{r}$

where $\psi_{0}$ is the constant coefficient of the model; $\psi_{i}, \psi_{i i}$, and $\psi_{i j}$ represent as the linear interactive coefficients, quadratic, and second order constants. $x_{i}$ and $x_{j}$ are variables and $D_{r}$ denotes to error. Furthermore, for the parameter interaction analysis, ANOVA (analysis of variance) was used. From the ANOVA table, the $F$ and $P$ values for both the responses, percentage removal, and capacity were attained. The validation of the quadric model was analyzed by various $R^{2}$ values. So it is concluded that model terms are significant with a confidence level of $95 \%$. For optimizing both the responses, a multi-response optimization tool was used with a desirability function of RSM (Sangal et al. 2013).

\section{Batch adsorption measurements and data analysis}

In this work, initially, thirty experiments were designed to assess the relationship between dependent and independent variables created by CCD/RSM (Table 2). The fresh stock solutions of required concentrations were prepared daily using deionized water. The sets of experiments were performed under batch process followed by RSM-suggested experimental list. For every experiment, $100 \mathrm{ml}$ DOX solution (of definite dose) was taken in 150-mL stoppered conical flasks and its $\mathrm{pH}$ was adjusted using the desired concentrations of acid/base solutions. The predetermined amount of RHA was added to the solution and it was agitated in an incubator shaker at $150 \mathrm{rpm}$ and $303 \mathrm{~K}$ temperature. After a programmed time, mixtures of DOX and RHA were separated with the help of Whatman no.1 filter paper, and the remains were characterized for DOX content $\left(\mathrm{C}_{\mathrm{e}}\right)$ using a dual-beam UV-visible spectrophotometer (HITACHI U2000 model) at wavelength $\left(\lambda_{\max }\right)=345 \mathrm{~nm}$ with the help of the calibration curve. The $X_{1}$ and $X_{2}$ responses of RHA were then examined using the following equations:

$X_{1}=\frac{\left(C_{0}-C_{f}\right)}{C_{0}} \times 100$
Table 1 Different range of variables and levels of the design model

\begin{tabular}{lllllll}
\hline Factors & Variables & \multicolumn{5}{l}{ Range of actual and coded variables } \\
\cline { 3 - 6 } & & $(-2)$ & $(-1)$ & $(0)$ & $(+1)$ & $(+2)$ \\
\hline $\mathrm{A}$ & $\mathrm{pH}$ & 2 & 4 & 6 & 8 & 10 \\
$\mathrm{~B}$ & Dose (g/L) & 5 & 10 & 15 & 20 & 25 \\
$\mathrm{C}$ & DOX conc. (mg/L) & 10 & 30 & 50 & 70 & 90 \\
$\mathrm{D}$ & Time (min) & 10 & 195 & 380 & 565 & 750 \\
\hline
\end{tabular}


Table 2 Design of experimentation for the adsorption of DOX by RHA

\begin{tabular}{|c|c|c|c|c|c|c|c|}
\hline Std & Run & $\mathrm{pH}$ & Dose $(\mathrm{g} / \mathrm{L})$ & $\begin{array}{l}\text { DOX conc. } \\
(\mathrm{mg} / \mathrm{L})\end{array}$ & Time (min) & $\begin{array}{l}\% \text { DOX } \\
\text { removal }\left(X_{1}\right)\end{array}$ & $\begin{array}{l}\text { Adsorption } \\
\text { capacity } \\
\left(\mathrm{X}_{2}\right)\end{array}$ \\
\hline 14 & 1 & 8.0 & 10.0 & 70.0 & 565.0 & 96.66 & 6.76 \\
\hline 3 & 2 & 4.0 & 20.0 & 30.0 & 195.0 & 91.70 & 1.37 \\
\hline 11 & 3 & 4.0 & 20.0 & 30.0 & 565.0 & 92.21 & 1.38 \\
\hline 4 & 4 & 8.0 & 20.0 & 30.0 & 195.0 & 90.67 & 1.36 \\
\hline 18 & 5 & 10.0 & 15.0 & 50.0 & 380.0 & 95.31 & 3.17 \\
\hline 25 & 6 & 6.0 & 15.0 & 50.0 & 380.0 & 94.08 & 3.13 \\
\hline 22 & 7 & 6.0 & 15.0 & 90.0 & 380.0 & 95.88 & 5.75 \\
\hline 9 & 8 & 4.0 & 10.0 & 30.0 & 565.0 & 94.42 & 2.83 \\
\hline 27 & 9 & 6.0 & 15.0 & 50.0 & 380.0 & 94.21 & 3.14 \\
\hline 12 & 10 & 8.0 & 20.0 & 30.0 & 565.0 & 90.47 & 1.35 \\
\hline 5 & 11 & 4.0 & 10.0 & 70.0 & 195.0 & 98.12 & 6.86 \\
\hline 19 & 12 & 6.0 & 5.00 & 50.0 & 380.0 & 96.87 & 9.68 \\
\hline 1 & 13 & 4.0 & 10.0 & 30.0 & 195.0 & 94.98 & 2.84 \\
\hline 23 & 14 & 6.0 & 15.0 & 50.0 & 10.0 & 95.47 & 3.18 \\
\hline 29 & 15 & 6.0 & 15.0 & 50.0 & 380.0 & 94.28 & 3.14 \\
\hline 24 & 16 & 6.0 & 15.0 & 50.0 & 750.0 & 94.99 & 3.16 \\
\hline 30 & 17 & 6.0 & 15.0 & 50.0 & 380.0 & 94.31 & 3.14 \\
\hline 7 & 18 & 4.0 & 20.0 & 70.0 & 195.0 & 96.86 & 3.39 \\
\hline 10 & 19 & 8.0 & 10.0 & 30.0 & 565.0 & 93.30 & 2.79 \\
\hline 17 & 20 & 2.0 & 15.0 & 50.0 & 380.0 & 96.60 & 3.22 \\
\hline 21 & 21 & 6.0 & 15.0 & 10.0 & 380.0 & 87.64 & 0.58 \\
\hline 20 & 22 & 6.0 & 25.0 & 50.0 & 380.0 & 92.31 & 1.84 \\
\hline 15 & 23 & 4.0 & 20.0 & 70.0 & 565.0 & 95.73 & 3.35 \\
\hline 26 & 24 & 6.0 & 15.0 & 50.0 & 380.0 & 94.13 & 3.13 \\
\hline 8 & 25 & 8.0 & 20.0 & 70.0 & 195.0 & 95.67 & 3.34 \\
\hline 2 & 26 & 8.0 & 10.0 & 30.0 & 195.0 & 93.94 & 2.81 \\
\hline 13 & 27 & 4.0 & 10.0 & 70.0 & 565.0 & 97.14 & 6.80 \\
\hline 16 & 28 & 8.0 & 20.0 & 70.0 & 565.0 & 94.87 & 3.32 \\
\hline 28 & 29 & 6.0 & 15.0 & 50.0 & 380.0 & 94.26 & 3.14 \\
\hline 6 & 30 & 8.0 & 10.0 & 70.0 & 195.0 & 97.69 & 6.83 \\
\hline
\end{tabular}

Similarly, the sorption capacity, $q_{e}(\mathrm{mg} / \mathrm{g})$ was determined as follows:

$q_{e}=\frac{\left(C_{0}-C_{e}\right)}{m} \times V$

Here, $C_{\mathrm{o}}$ and $C_{\mathrm{e}}$ denote the original and equilibrium DOX concentrations, $C_{\mathrm{f}}$ denotes the final concentration of DOX $(\mathrm{mg} / \mathrm{L}), V$ is the sample volume $(\mathrm{mL})$, and $m(\mathrm{~g})$ denotes the amount of RHA.

\section{Solidification and stabilization (S/S) studies of DOX loaded RHA}

The S/S is generically defined as a chemical and physical alteration technique for reducing the movement of contaminants from wastes by converting them into the chemically inert form. Among various S/S binders, cement-based systems are usually evaluated due to its low cost, wideranging disposal, and adaptability (Bie et al. 2015). In this technique, the cementing material is mixed with contaminated solid and water and due to the rapid settling, a rigid structure is formed which develops strength in the mixture, and contaminants are bonded inside. So it is a process that makes an inert solidified complex structure that does not react further while changing the atmospheric conditions (Poon et al. 2004).

To detect the effect of binding agent on the leachability behavior of DOX, antibiotic carrying exhausted RHA and Portland cement were mixed with different adsorbent to cement ratios (Table 3). Furthermore, beads of around $2 \mathrm{~cm}$ diameter were prepared with the help of water and it was kept for $24 \mathrm{~h}$ in natural atmospheric condition. These beads were incubated at room temperature for 15 days in $100 \mathrm{~mL}$ distilled water and the water level was maintained in the testing beakers (Kaur et al. 2021a). After that, the 
Table 3 Different used combinations of exhausted/loaded adsorbent (RHA-DOX) and cement for solidification study

\begin{tabular}{lll}
\hline Sample No & Mass of adsorbent + cement in mixture & $\begin{array}{l}\text { Mass ratio of } \\
\text { adsorbent to } \\
\text { cement }\end{array}$ \\
\hline 1 & 1 g adsorbent +5 g cement & $1: 5$ \\
2 & 2 g adsorbent +4 g cement & $1: 2$ \\
3 & 3 g adsorbent +3 g cement & $1: 1$ \\
4 & 4 g adsorbent +2 g cement & $2: 1$ \\
5 & 5 g adsorbent +1 g cement & $5: 1$ \\
\hline
\end{tabular}

sample (leachate) was tested for DOX concentration using UV-visible spectrophotometer at $345 \mathrm{~nm}$ and the encapsulation percentage was calculated using Eq. (4).

Capsulationpercentage $=\frac{\left(C_{a}-C_{l}\right)}{C_{a}} \times 100$

where $C_{a}$ and $C_{l}$ indicate the DOX amounts $(\mathrm{mg} / \mathrm{L})$ in RHA and leachate.

\section{Cytotoxicity analysis}

After completing the solidification and stabilization process, the toxic effects of different leachate samples were analyzed by adopting the agar cup process (Collier et al. 2006). The test was performed on Petri plates by agar cup method. Two microbial species, E. coli (EC) and Bacillus subtilis (BC), were restored in nutrient medium. Furthermore, Mueller and Hinton agar (MHA) media was used to examine the toxicity test and then spreading was done on petri plates through selected bacterial strains. Two to four wells were made per plate using a $0.5-\mathrm{mm}$ sterilized cork borer, and a $0.25 \mu \mathrm{l}$ of leachate sample was put into each well. For comparison purpose, DOX solution of different concentrations ( 0.1 to $10 \mathrm{ppm}$ ) was also put in few wells. After that, plates were kept in an incubator at $35 \pm 0.1{ }^{\circ} \mathrm{C}$ for $24 \mathrm{~h}$ and the results were perceived.

\section{Results and discussion}

\section{Characterization of the RHA}

The FTIR spectra of DOX, fresh RHA, and DOX-loaded RHA are shown in Fig. 1. In DOX spectrum, the wide peak amid 3412 to $3667 \mathrm{~cm}^{-1}$ is dedicated to $-\mathrm{OH}$ groups. Sharp peaks at $1670 \mathrm{~cm}^{-1}$ and $1647 \mathrm{~cm}^{-1}$ represent to $\mathrm{C}=\mathrm{O}$ and amide I groups, respectively. The absorption bands at $1617 \mathrm{~cm}^{-1}$ and $1581 \mathrm{~cm}^{-1}$ are particular for $-\mathrm{COOH}$ and amide II groups, respectively. Moreover, the vibration band at $1245 \mathrm{~cm}^{-1}$ is attributed to the amide III group. In RHA,

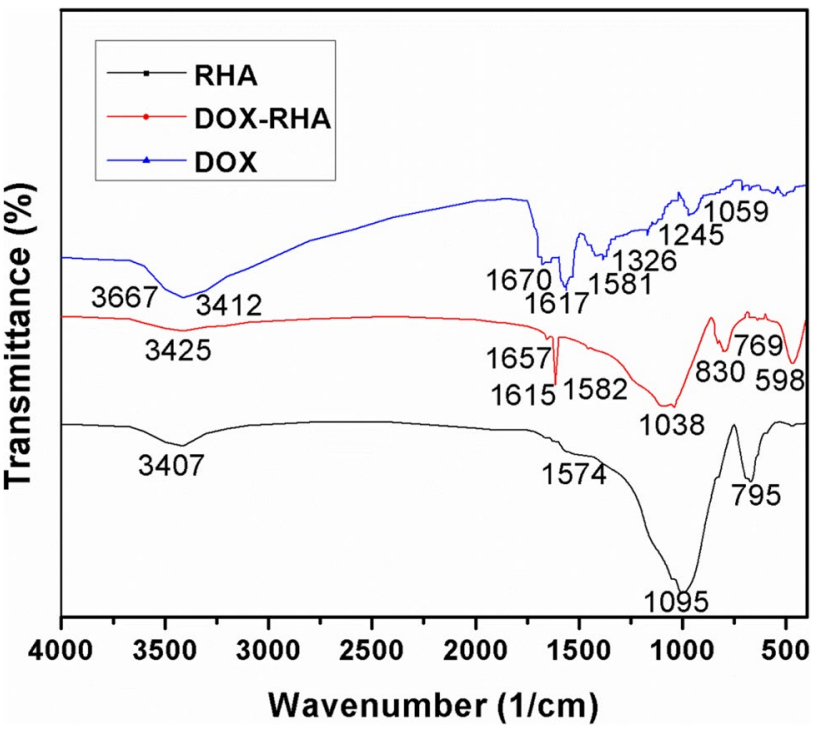

Fig. 1 FTIR spectra of RHA, DOX-RHA, and DOX

before the adsorption of DOX, the presence of a wide peak amid 3100 to $3700 \mathrm{~cm}^{-1}$ is recognized as the both free and H-bonded $\mathrm{OH}$ bands present on the exterior of RHA (Srivastava et al. 2006). In the spectrum, the predominantly noticeable peaks correlate with the $\mathrm{Si}-\mathrm{O}, \mathrm{Si}-\mathrm{OH}$, and $\mathrm{Si}-\mathrm{O}-\mathrm{Si}$ groups at regions 1095 and $795 \mathrm{~cm}^{-1}$, respectively. According to the reported literature, the main component of RHA is silicon that exists in the form of $\mathrm{SiO}_{2}$. After the adsorption, many changes were observed in peak patterns and the vibration of DOX was observed in the loaded RHA sample. The distinctive absorption bands were diagnosed which were correlated with DOX at $1657 \mathrm{~cm}^{-1}, 1615 \mathrm{~cm}^{-1}, 1582 \mathrm{~cm}^{-1}$, $1038 \mathrm{~cm}^{-1}, 769 \mathrm{~cm}^{-1}$, and $598 \mathrm{~cm}^{-1}$ in the loaded sample. Moreover, shifting in peaks from 1095 to $1038 \mathrm{~cm}^{-1}$ and 795 to $769 \mathrm{~cm}^{-1}$ shows the deformation of $\mathrm{Si}-\mathrm{O}, \mathrm{Si}-\mathrm{OH}$, and $\mathrm{Si}-\mathrm{O}-\mathrm{Si}$ groups that points out that DOX antibiotic has been positively performed (Abou-Mesalam 2003).

XRD diffraction patterns (Fig. S2) of blank RHA showed $\mathrm{SiO}_{2}$, cristobalite, and Trydimite. On the other hand, some sharp and narrow peaks seen in the loaded sample at 2 theta 20.25 and 37.2 explain the amorphous nature of RHA due to the presence of $\mathrm{SiO}_{2}$ and cristobalite. These were the deviations observed between blank RHA and loaded RHA adsorbent. The specific surface area of the DOX was evaluated by using the nitrogen adsorption-desorption method well established on the BET model at temperature $77 \mathrm{~K}$ in the presence of liquid nitrogen. As a result, the specific surface area and average BET pore diameter of adsorbent were evaluated as $32.6 \mathrm{~m}^{2} / \mathrm{g}$ and $6.5 \mathrm{~nm}$, respectively. Thus, it indicates the mesoporous nature of RHA due to $d<20 \mathrm{~A}^{0}$ and proves to be a suitable adsorbent for the sorption. The average particle size of the used RHA was found to be $146.3 \mu \mathrm{m}$. Moreover, 
the SEM-EDX pattern of RHA and DOX-RHA is shown in Fig. 2. The particles have a well-arranged pattern on the external surface of RHA which is shown in Fig. 2a; the internal surface of particle is highly porous and fibrous in nature. Therefore, the existence of mesopores and macropores is supportive for the sorption of DOX molecules on their surface. Figure $2 \mathrm{c}$ represents that all the pores are filled with DOX adsorbate and it forms a well-structured network on the RHA surface. Furthermore, the EDX spectrum of both samples (Fig. 2b, d) indicates that the major constituents of RHA are silica and oxygen that are accumulated as $\mathrm{SiO}_{2}$. The main differences are seen in these both $(\mathrm{Si}$ and $\mathrm{O}) \mathrm{com}$ ponents and some other components were also found in lesser concentrations as shown in Fig. 2b, d.

\section{Model suitability and statistical investigation}

The experimental runs suggested by the CCD model of RSM were completed, and the responses $\left(\mathrm{X}_{1}\right)$ and $\left(\mathrm{X}_{2}\right)$ were calculated (Table 2 ). The statistical analysis results of experimental data were found using the variance of the ANOVA table generated by the RSM. It involves a sum of squares, $F$-value, probability values, etc.; these were analyzed (Table 4) and it was recommended by the sum of squares (sequential model) that the quadratic model was the most suitable for the experimental data. The calculated values of 52.36 and 25.11 were found for acceptable precision of both responses $\left(\mathrm{X}_{1}\right)$ and $\left(\mathrm{X}_{2}\right)$ individually. On the other hand, the model $F$-values for $\mathrm{X}_{1}$ and $\mathrm{X}_{2}$ were 148.87 and 37.17 as listed in Table 4.

Thus, it supported the value of the quadratic model. So, the final equations are given in the form of following second-order polynomial quadratic model:

$$
\begin{aligned}
\mathrm{X}_{1} & =99.52-(1.61 \times \mathrm{pH})-(0.52 \times \mathrm{m}) \\
& +(0.19 \times \mathrm{C})-(6.47 \times 10-3 \times \mathrm{t})+\left(0.11 \times \mathrm{pH}^{2}\right) \\
& +\left(5.57 \times 10^{-3} \times \mathrm{m}^{2}\right)-\left(1.42 \times 10^{-3} \times \mathrm{C}^{2}\right) \\
& +\left(8.73 \times 10^{-6} \times \mathrm{t}^{2}\right)-(0.01 \times \mathrm{pH} \times \mathrm{m})+\left(3.06 \times 10^{-3} \times \mathrm{pH} \times \mathrm{C}\right) \\
& -\left(8.58 \times 10^{-5} \times \mathrm{pH} \times \mathrm{t}\right)+\left(3.20 \times 10^{-3} \times \mathrm{m} \times \mathrm{C}\right) \\
& +\left(1.07 \times 10^{-4} \times \mathrm{m} \times \mathrm{t}\right)-\left(5.15 \times 10^{-5} \times \mathrm{C} \times \mathrm{t}\right) \\
\mathrm{X}_{2} & =5.27+(0.06 \times \mathrm{pH})-(0.78 \times \mathrm{m}) \\
& +(0.15 \times \mathrm{C})+\left(6.62 \times 10^{-4} \times \mathrm{t}\right)-\left(6.20 \times 10^{-3} \times \mathrm{pH}^{2}\right) \\
& +\left(0.02 \times \mathrm{m}^{2}\right)-\left(8.07 \times 10^{-5} \times \mathrm{C}^{2}\right)-\left(9.01 \times 10^{-7} \times \mathrm{t}^{2}\right) \\
& +\left(9.45 \times 10^{-5} \times \mathrm{pH} \times \mathrm{m}\right)-\left(4.595 \times 10^{-5} \times \mathrm{pH} \times \mathrm{C}\right) \\
& -\left(8.51 \times 10^{-7} \times \mathrm{pH} \times \mathrm{t}\right)-\left(5.02 \times 10^{-3} \times \mathrm{m} \times \mathrm{C}\right) \\
& +\left(7.72 \times 10^{-6} \times \mathrm{m} \times \mathrm{t}\right)-\left(2.99 \times 10^{-6} \times \mathrm{C} \times \mathrm{t}\right)
\end{aligned}
$$

The close to unity values of $R^{2}, \mathrm{R}_{\mathrm{adj}}^{2}$, and $\mathrm{R}_{\mathrm{pre}}^{2}$ confirmed that the quadratic polynomial model to signify the

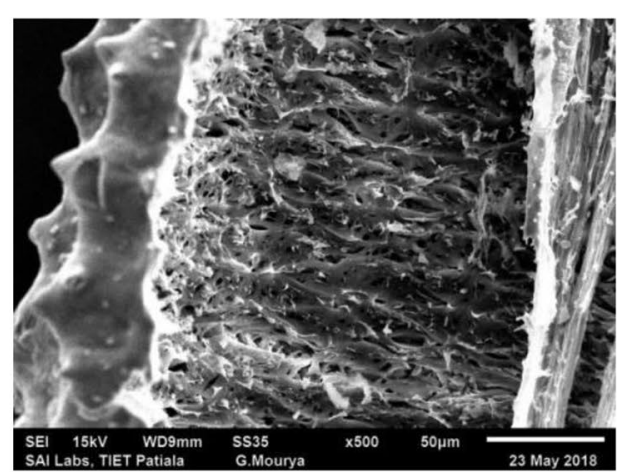

(a)

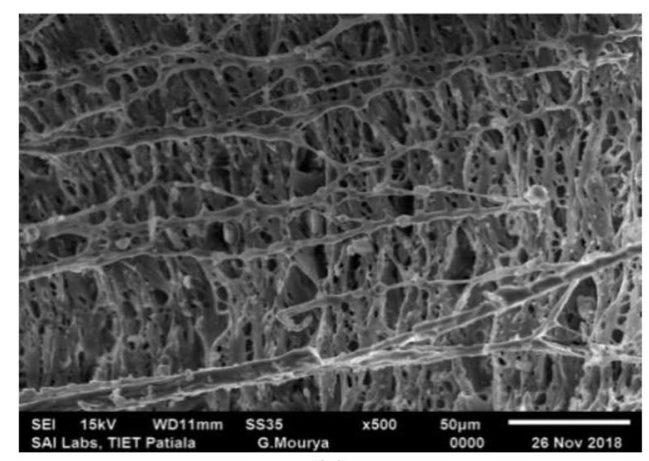

(c)

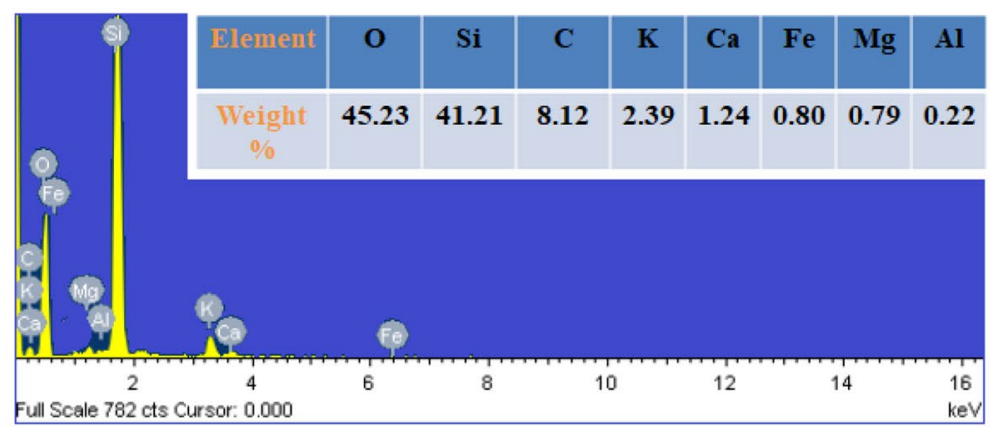

(b)

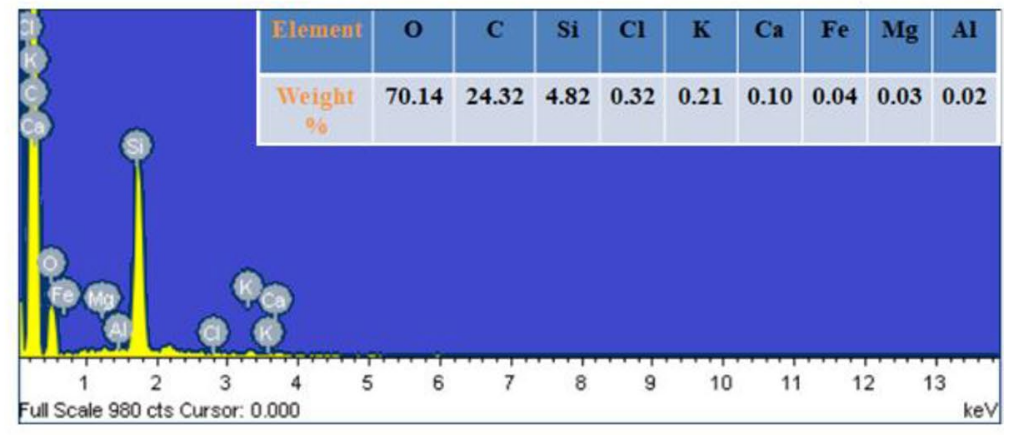

(d)

Fig. 2 SEM-EDX analysis of RHA and DOX loaded RHA (a, b, c, and d) 
Table 4 ANOVA tables for the \% DOX removal and capacity

\begin{tabular}{|c|c|c|c|c|c|c|c|c|c|c|}
\hline \multicolumn{6}{|c|}{$\%$ DOX removal $\left(\mathrm{X}_{1}\right)$} & \multicolumn{5}{|c|}{ Adsorption capacity $\left(\mathrm{X}_{2}\right)$} \\
\hline Source & Sum of squares & $\mathrm{DF}$ & Mean square & $F$ value & Prob $>F$ & Sum of squares & $\mathrm{DF}$ & Mean square & $F$ value & Prob $>F$ \\
\hline Model & 154.49 & 14 & 11.03 & 148.87 & $<0.0001$ & 116.42 & 14 & 8.32 & 37.17 & $<0.0001$ \\
\hline A & 4.58 & 1 & 4.58 & 61.78 & $<0.0001$ & $4.491 \times 10^{-3}$ & 1 & $4.491 \times 10^{-3}$ & 0.020 & 0.8892 \\
\hline B & 30.77 & 1 & 30.77 & 415.17 & $<0.0001$ & 52.12 & 1 & 52.12 & 232.97 & $<0.0001$ \\
\hline $\mathrm{C}$ & 94.09 & 1 & 94.09 & 1269.34 & $<0.0001$ & 48.87 & 1 & 48.87 & 218.40 & $<0.0001$ \\
\hline $\mathrm{D}$ & 1.41 & 1 & 1.41 & 19.05 & 0.0006 & $3.101 \times 10^{-3}$ & 1 & $3.101 \times 10^{-3}$ & 0.014 & 0.9078 \\
\hline $\mathrm{A}^{2}$ & 6.31 & 1 & 6.31 & 85.15 & $<0.0001$ & 0.017 & 1 & 0.017 & 0.076 & 0.7872 \\
\hline $\mathrm{B}^{2}$ & 0.53 & 1 & 0.53 & 7.19 & 0.0171 & 10.45 & 1 & 10.45 & 46.71 & $<0.0001$ \\
\hline $\mathrm{C}^{2}$ & 8.87 & 1 & 8.87 & 119.65 & $<0.0001$ & 0.029 & 1 & 0.029 & 0.13 & 0.7255 \\
\hline $\mathrm{D}^{2}$ & 2.45 & 1 & 2.45 & 33.09 & $<0.0001$ & 0.026 & 1 & 0.026 & 0.12 & 0.7375 \\
\hline $\mathrm{AB}$ & 0.19 & 1 & 0.19 & 2.60 & 0.1276 & $1.430 \times 10^{-5}$ & 1 & $1.430 \times 10^{-5}$ & $6.391 \times 10^{-5}$ & 0.9937 \\
\hline $\mathrm{AC}$ & 0.24 & 1 & 0.24 & 3.26 & 0.0913 & $5.407 \times 10^{-5}$ & 1 & $5.407 \times 10^{-5}$ & $2.416 \times 10^{-4}$ & 0.9878 \\
\hline $\mathrm{AD}$ & 0.016 & 1 & 0.016 & 0.22 & 0.6474 & $1.589 \times 10^{-6}$ & 1 & $1.589 \times 10^{-6}$ & $7.101 \times 10^{-6}$ & 0.9979 \\
\hline $\mathrm{BC}$ & 1.64 & 1 & 1.64 & 22.16 & 0.0003 & 4.04 & 1 & 4.04 & 18.05 & 0.0007 \\
\hline $\mathrm{BD}$ & 0.16 & 1 & 0.16 & 2.15 & 0.1633 & $8.163 \times 10^{-4}$ & 1 & $8.163 \times 10^{-4}$ & $3.649 \times 10^{-3}$ & 0.9526 \\
\hline $\mathrm{CD}$ & 0.58 & 1 & 0.58 & 7.86 & 0.0134 & $1.965 \times 10^{-3}$ & 1 & $1.965 \times 10^{-3}$ & $8.782 \times 10^{-3}$ & 0.9266 \\
\hline Residual & 1.11 & 15 & 0.074 & & & 3.36 & 15 & 0.22 & & \\
\hline Lack of fit & 1.07 & 10 & 0.11 & 12.62 & 0.0060 & 3.36 & 10 & 0.34 & 35643.63 & $<0.0001$ \\
\hline Pure error & 0.042 & 5 & $8.47 \times 10^{-3}$ & & & $4.708 \times 10^{-5}$ & 5 & $9.416 \times 10^{-6}$ & & \\
\hline Cor total & 155.60 & 29 & & & & 119.78 & 29 & & & \\
\hline
\end{tabular}

$A, \mathrm{pH} ; B$, dose (m, g/L); $C$, DOX conc. $\left(C_{0}, \mathrm{mg} / \mathrm{L}\right) ; D$, time $(t, \mathrm{~min})$

Table 5 Various statistic $R$-squared values suggested by CCD for different responses

\begin{tabular}{llll}
\hline Responses & $R$-squared & Adj $R$-squared & Pred $R$-squared \\
\hline \% DOX removal $\left(\mathrm{X}_{1}\right)$ & 0.99 & 0.98 & 0.96 \\
Adsorption capacity & 0.97 & 0.94 & 0.83 \\
$\left(\mathrm{X}_{2)}\right.$ & & & \\
\hline
\end{tabular}

positive associations towards both responses. It is shown in Table 5. Further assessment of the model adequacy has been investigated by plotting actual versus predicted values. Excellent correlation shown in Fig. 3 reveals the adequate relationship among the experimental and calculated values (Table 6).

\section{Response surface analysis and optimization}

The 3-D response surface plots found from the RSM/CCD model for two responses \% DOX removal $\left(\mathrm{X}_{1}\right)$ and capacity $\left(\mathrm{X}_{2}\right)$ with different adsorption parameters, i.e., $\mathrm{C}(\mathrm{mg} / \mathrm{L})$, $m(\mathrm{~g} / \mathrm{L}), t(\mathrm{~min})$, and $\mathrm{pH}$ values, are shown in Fig. 4. These graphs illustrate the variations within different dependent and independent parameters which facilitate the analysis for single and simultaneous influence of the parameters on studied responses. The corresponding values of both the responses with these parameters for DOX uptake are summarized in Table 2.

Figure $4 \mathrm{a}$ and $\mathrm{d}$ represent the interactive influence of $C$ and $m$ on the responses $\mathrm{X}_{1}$ and $\mathrm{X}_{2}$, respectively. At any adsorbent dose, DOX uptake increases rapidly with enhancement in initial DOX concentration. This increment is continuous for high adsorbent dose but at low dose, \% removal becomes ultimately constant at very high DOX concentrations. From Fig. 4d, it may be seen that increasing RHA dosage results in a decreasing adsorption capacity, whereas it increases with the DOX amount in solution. The maximum DOX removal was observed at the minimum RHA dosage and maximum DOX concentration. At constant RHA dose (5 g/L) and DOX concentration $(90 \mathrm{mg} / \mathrm{L})$, a maximum DOX uptake capacity of $>13 \mathrm{mg} / \mathrm{g}$ was obtained. Furthermore, the relations between DOX initial concentrations $(\mathrm{mg} / \mathrm{L})$ and time $(\mathrm{min})$ were studied and are represented in Fig. 4b and e. As can be seen from Fig. 4b, \% DOX removal enhanced rapidly with increment in its initial concentration till $\approx 80 \mathrm{mg} / \mathrm{L}$, because of the larger amount of DOX competing for the available adsorption sites on RHA. Moreover, it was also noted that for very high initial concentrations, less adsorption time favors the DOX uptake, which might be ascribed to the desorption at more adsorption time. The interaction 


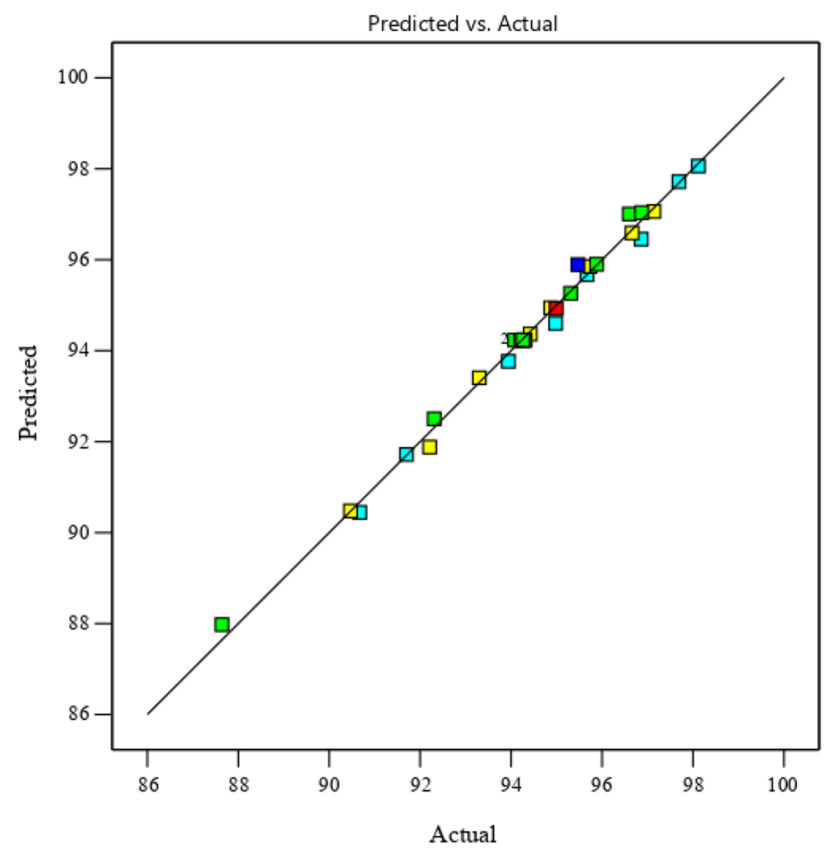

(a)

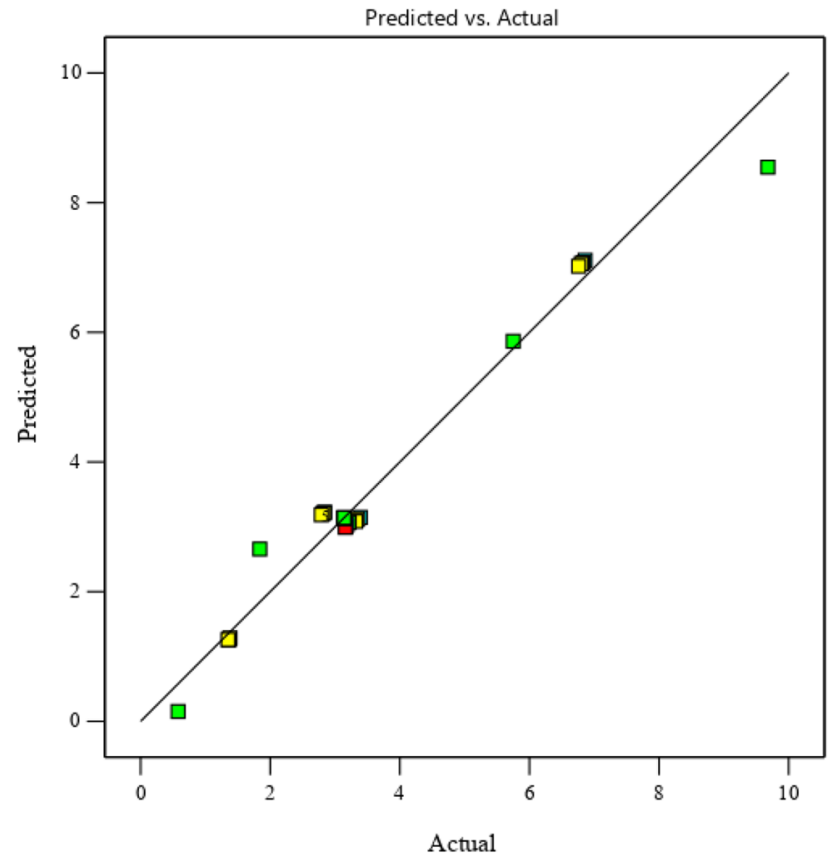

(b)

Fig. 3 The actual data versus predicted data for removal (\%) and capacity (mg/g) of DOX (a, b)

Table 6 Comparison of experimental and predicted responses values at optimized condition $(m=5 \mathrm{~g} / \mathrm{L}, t=85.85 \mathrm{~min}, \mathrm{pH}=6$, DOX concentration $=89.73 \mathrm{mg} / \mathrm{L}$ )

\begin{tabular}{lll}
\hline Responses & Predicted value & Experimental value \\
\hline$\%$ removal $\left(\mathrm{X}_{1}\right)$ & $99.51 \%$ & $98.85 \%$ \\
Capacity $\left(\mathrm{X}_{2}\right)$ & 16.25 & 17.74 \\
\hline
\end{tabular}

between solution $\mathrm{pH}$ and initial concentration of DOX is exhibited in Fig. $4 \mathrm{c}$ and $\mathrm{f}$. As it is evident from the figures, when initial DOX concentration increases, the removal rate of DOX by RHA increases significantly regardless of the changes in solution $\mathrm{pH}$. In general, the influence of initial DOX concentration on DOX adsorption is greater than that of solution $\mathrm{pH}$.

In DOX-RHA adsorption, optimization study was also performed for enhancing the performances $X_{1}$ and $\mathrm{X}_{2}$ using the RSM. The optimization restrictions set for this purpose are given in Table $\mathrm{S} 1$. The conditions were evaluated as $m=5 \mathrm{~g} / \mathrm{L}, t=85.85 \mathrm{~min}$ and $\mathrm{pH}=6$ with both responses as $99.51 \%$ and $16.25 \mathrm{mg} / \mathrm{g}$, respectively. Further we examined the results of responses (percentage removal and capacity). These were $98.85 \%$ and $17.74 \mathrm{mg} / \mathrm{g}$, respectively, which agree well with the advised values (Table 6).

\section{Kinetics of DOX adsorption}

To understand the kinetics of adsorption between DOX and RHA and calculate the kinetic parameters, pseudofirst-order- and pseudo-second-order kinetics models were used. It was performed under optimized conditions $(\mathrm{pH}=6$, $m=5 \mathrm{~g} / \mathrm{L}$, and time $=85.85 \mathrm{~min})$ at different stock concentrations of DOX $(40,70$, and $100 \mathrm{mg} / \mathrm{L})$. These two model equations can be given by the following expressions:

Pseudo-1 1st-order model is represented as follows (Malik 2003):

$q_{t}=q_{e}\left[1-\exp \left(-k_{f} t\right)\right]$

Pseudo-2nd-order model is signified as follows (Ho and McKay 1994):

$q_{t}=\frac{t k_{s} q_{e}^{2}}{1+t k_{s} q_{e}}$

The initial adsorption rate, $h(\mathrm{~g} / \mathrm{mg} / \mathrm{min})$, may be calculated with the help of $K_{\mathrm{s}}$ and $q_{\mathrm{e}}$ magnitudes and are given as follows:

$h=k_{s} q_{e}^{2}$

where $q_{\mathrm{e}}$ and $q_{\mathrm{t}}(\mathrm{mg} / \mathrm{g})$ refer to the equilibrium amount of DOX adsorbed in duration $t$ minutes, $k_{\mathrm{f}}\left(\mathrm{min}^{-1}\right)$ and $k_{\mathrm{s}}$ 


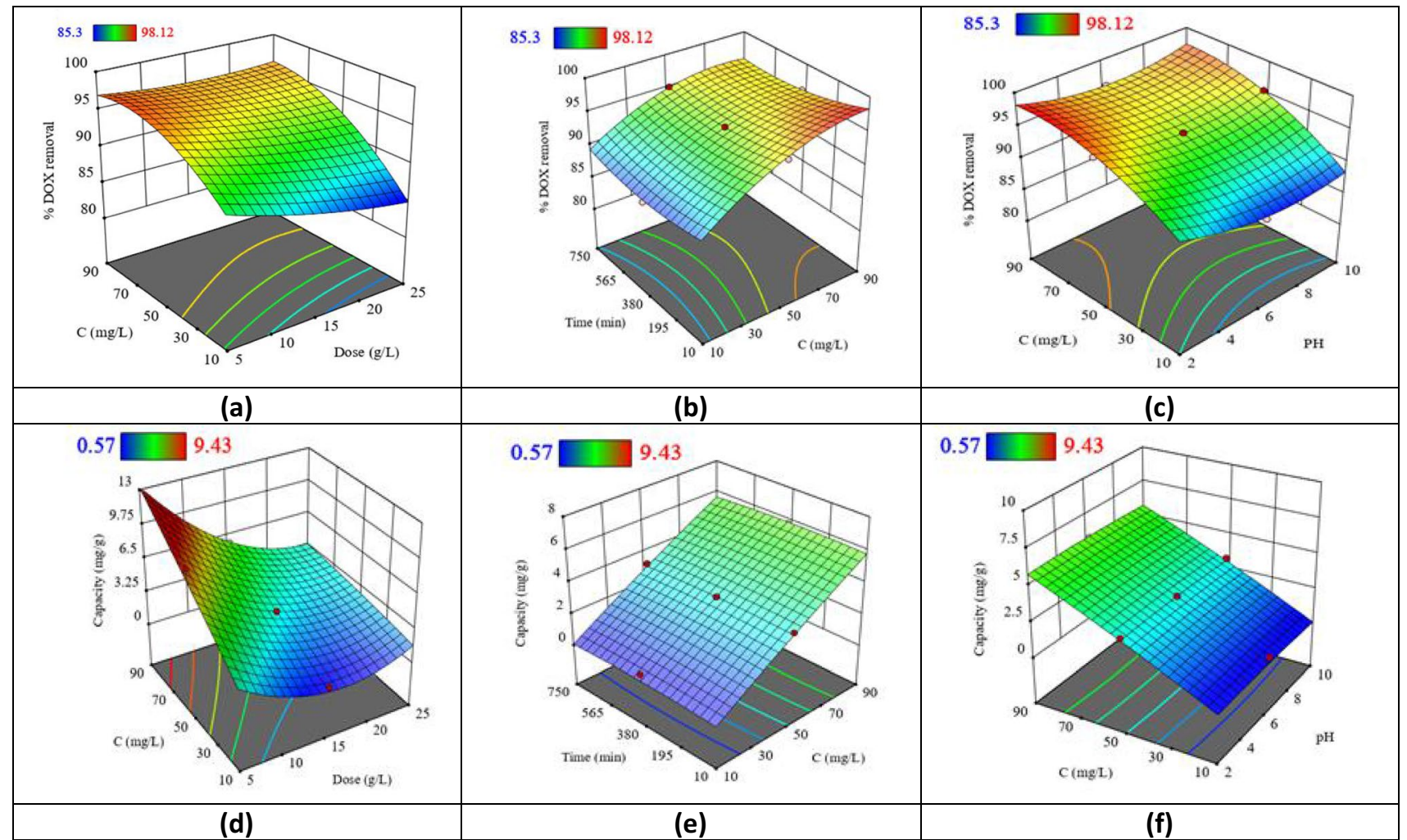

Fig. 4 3D-graph for the adsorptive removal of DOX from aqueous solution $(\mathbf{a}, \mathbf{b}, \mathbf{c}) \%$ removal versus concentration of DOX, mass, time, and $\mathrm{pH}(\mathbf{d}, \mathbf{e}, \mathbf{f})$ capacity versus, DOX concentration, dose, $t$, and $\mathrm{pH}$

Fig. 5 Pseudo-first and secondorder adsorption kinetics at different initial concentrations (a) Weber-Morris plot versus $t$ for DOX removal by RHA (b)

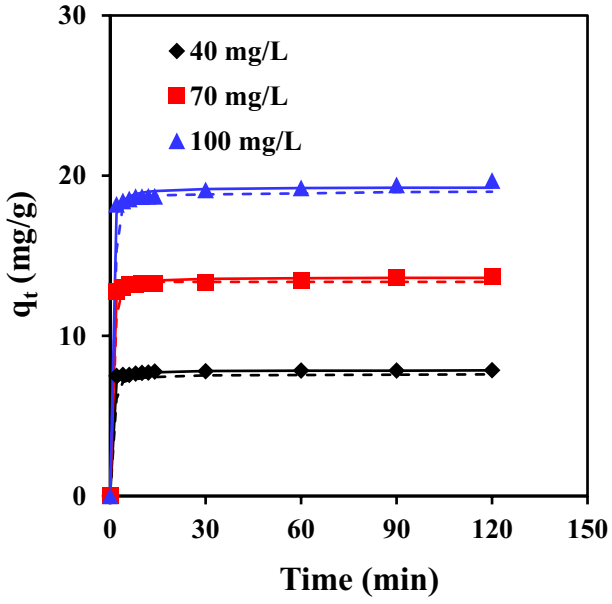

(a)

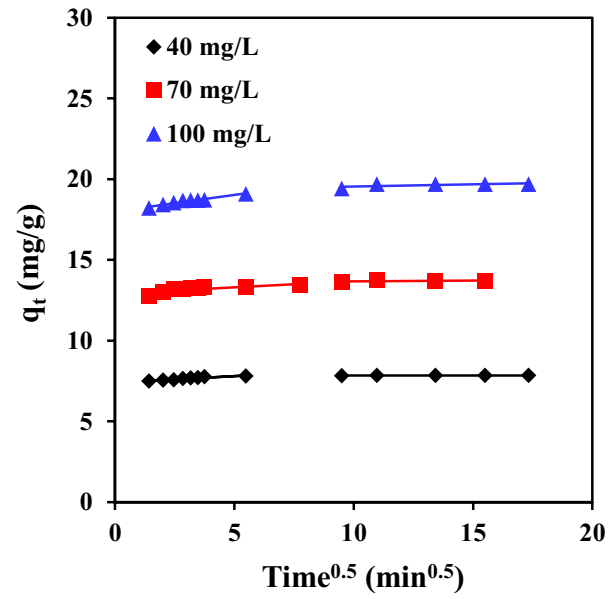

(b) $(\mathrm{g} / \mathrm{mg} / \mathrm{min})$ are the reaction constant rates for pseudo-1st and pseudo-2nd orders. As shown in Fig. 5a, initially, a sharp increase in sorption takes place due to the availability of high number of the active site on the adsorbent surface and equilibrium was attained within $30 \mathrm{~min}$. The experimental data were correlated with these kinetic models with the help of nonlinear regression. It is evident from the figure that pseudo-2nd-order kinetic model fitted better with the experimental values than pseudo-1st-order model. All the evaluated kinetic parameters, $R^{2}$, and error values are listed in Table 7. High $R^{2}$ values and low MPSD error at all concentrations (40,70, and $100 \mathrm{mg} / \mathrm{L})$ confirm that DOX sorption on the RHA follows the second-order kinetics.

In addition, the intra-particle diffusion (IPD) model was utilized to analyze the rate-controlling step in the DOX-RHA 
Table 7 Kinetic model parameters for DOX adsorption on RHA at optimized parameters ( $m=5 \mathrm{~g} / \mathrm{L}, t=85.85 \mathrm{~min}$, and $\mathrm{pH}=6)$

\begin{tabular}{|c|c|c|c|}
\hline & \multicolumn{3}{|c|}{$\mathrm{C}_{0}\left(\mathrm{mg} \mathrm{L}^{-1}\right)$} \\
\hline & 40 & 70 & 100 \\
\hline \multicolumn{4}{|l|}{ Pseudo-first-order } \\
\hline$k_{\mathrm{f}}\left(\min ^{-1}\right)$ & 1.190 & 0.910 & 0.802 \\
\hline$q_{\mathrm{e}, \exp }(\mathrm{mg} / \mathrm{g})$ & 7.849 & 13.716 & 19.694 \\
\hline$q_{\mathrm{e}, \mathrm{cal}}(\mathrm{mg} / \mathrm{g})$ & 7.794 & 13.370 & 19.200 \\
\hline$R^{2}$ (non-linear) & 0.988 & 0.992 & 0.990 \\
\hline MPSD & 16.91 & 6.157 & 8.695 \\
\hline \multicolumn{4}{|l|}{ Pseudo-second-order } \\
\hline$k_{\mathrm{s}}(\mathrm{g} / \mathrm{mg} / \mathrm{min})$ & 0.580 & 0.360 & 0.276 \\
\hline$h(\mathrm{mg} / \mathrm{g} / \mathrm{min})$ & 35.771 & 67.042 & 102.622 \\
\hline$q_{\mathrm{e}, \mathrm{cal}}(\mathrm{mg} / \mathrm{g})$ & 7.853 & 13.644 & 19.287 \\
\hline$R^{2}$ (non-linear) & 0.999 & 0.999 & 0.998 \\
\hline MPSD & 0.928 & 3.790 & 7.315 \\
\hline \multicolumn{4}{|l|}{ Weber Morris } \\
\hline$k_{i d 1}\left(\mathrm{mg} / \mathrm{g} \min ^{-1 / 2}\right)$ & 0.081 & 0.078 & 0.202 \\
\hline$I_{1}$ & 7.397 & 12.911 & 18.011 \\
\hline$R^{2}$ & 0.884 & 0.644 & 0.950 \\
\hline$k_{i d 2}\left(\mathrm{mg} / \mathrm{g} \mathrm{\operatorname {min } ^ { - 1 / 2 } )}\right.$ & 0.001 & 0.012 & 0.026 \\
\hline$I_{2}$ & 7.822 & 13.546 & 19.282 \\
\hline$R^{2}$ & 0.326 & 0.481 & 0.451 \\
\hline
\end{tabular}

adsorption process. The IPD model is represented by the following equation (Weber and Morris 1963):

$q_{t}=k_{\mathrm{id}} \mathrm{t}^{1 / 2}+I$

where $k_{i d}\left(\mathrm{mg} / \mathrm{g} \min ^{1 / 2}\right)$ denotes the IPD rate constant and $I(\mathrm{mg} / \mathrm{g})$ is the intercept of the intraparticle diffusion plot, which also represents the width of boundary layer. In the Weber and Morris plot, if the $q_{\mathrm{t}} \mathrm{vs} t^{1 / 2}$ graph is linear and it crosses through the origin, it confirms that the sorption is controlled solely by internal diffusion. The process of the DOX sorption on surface can be confirmed in two steps by the Weber and Morris plot in Fig. 5b. The initial step represents the quick adsorption due to the higher number of active sites on the sorbent surface. This is denoted as intraparticle diffusion mechanism. The second part diminishes the intraparticle diffusion and attains the ultimate stability point as represented in the 2 nd linear fragment in the figure. The second segment of the curves showed the equilibrium diffusion process. So, it can be said that the kinetic sorption process of DOX antibiotic onto RHA follows a multistep mechanism. The magnitude of IPD parameters $k_{i d}$ and $I$ is listed in Table 7.

\section{Isotherm modelling and thermodynamics}

The adsorption of the DOX on RHA was examined at distinct temperatures and concentrations and the suitability of equilibrium data was evaluated with the various isotherm models as shown in Fig. 6. Freundlich (Freundlich 1906), Redlich-Peterson (R-P) (Redlich and Peterson 1959), and Langmuir isotherms (Langmuir 1918) are represented by the following equations.

Langmuir model:

$q_{e}=\frac{q_{m} K_{L} C_{e}}{1+K_{L} C_{e}}$

Redlich-Peterson model:

$q_{e}=\frac{K_{R C_{e}}}{1+a_{R} C_{e}{ }^{\beta}}$

Freundlich model:

$q_{e=K_{F} C_{e}{ }^{1 / n}}$

where $q_{e}(\mathrm{mg} / \mathrm{g})$ is the specific equilibrium quantity of adsorbate, $C_{e}(\mathrm{mg} / \mathrm{L})$ is the equilibrium concentration of adsorbate, $\mathrm{q}_{\mathrm{m}}(\mathrm{mg} / \mathrm{g})$ is the maximum adsorption uptake. $K_{\mathrm{L}}, K_{\mathrm{F}}, \mathrm{a}_{\mathrm{R}}, K_{\mathrm{R}}$ are constants, and "n" represents the empirical constant.

The isotherm studies were performed at a temperature range of 288-318 K with DOX initial concentration of 40-300 mg/L. These experiments were directed at optimum conditions as $m=5 \mathrm{~g} / \mathrm{L}$, time $=85.85 \mathrm{~min}$, and $\mathrm{pH}$ is 6 . As displayed in Fig. 6, with the enhancement in temperature, the sorption rate increased due to the endothermic type of the operation. The non-linear fitting was performed and the experimental data suits well with the Langmuir, Freundlich, and R-P isotherm models with the high $R^{2}$ values. The values of parameters relevant to different isotherm models and correlation coefficient values are given in Table 8 . The high $R^{2}$ values represent stronger interactions between adsorbate-adsorbent and as the value of $\beta$ lies between 0 and 1 for R-P isotherm, it signifies that the sorption of DOX on RHA is a favorable operation.

The thermodynamic criterion is examined by Van't Hoff equation (Eq. (14)).

$\ln K_{d}=\frac{-\Delta G^{0}}{R T}=\frac{\Delta S^{0}}{R}-\frac{\Delta H^{0}}{R} \frac{1}{T}$

where $K_{d}$ is found from the slope of $\ln \frac{q_{e}}{C_{e}}$ versus $q_{e}, T$ is the temperature in $K, R$ represents the gas constant in $\mathrm{J} / \mathrm{mol} / \mathrm{K}$, $\Delta G^{\circ}, \Delta H^{\circ}$, and $\Delta S^{\circ}$ and are the changes in Gibb's free energy, standard enthalpy, and standard entropy. 
Fig. 6 Equilibrium adsorption isotherms for DOX adsorption on RHA at optimized parameters $(m=5 \mathrm{~g} / \mathrm{L}, t=85.85 \mathrm{~min}$, and $\mathrm{pH}=6)$ a Langmuir isotherm model b Freundlich isotherm model $\mathbf{c}$ RP isotherm model. Experimental data points given by symbols and the lines predicated by isotherm model

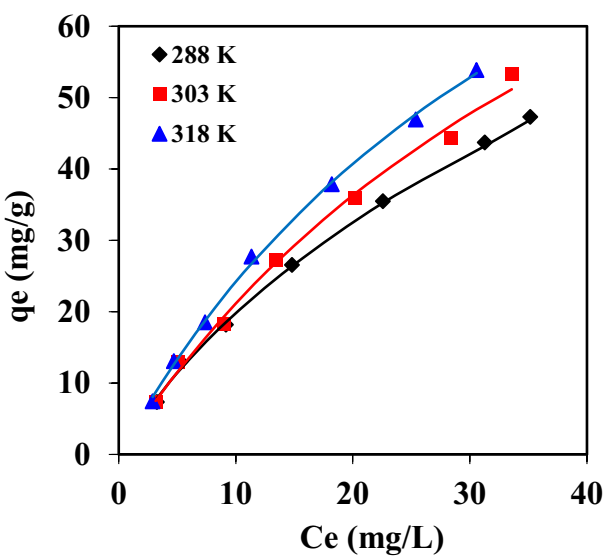

(a)

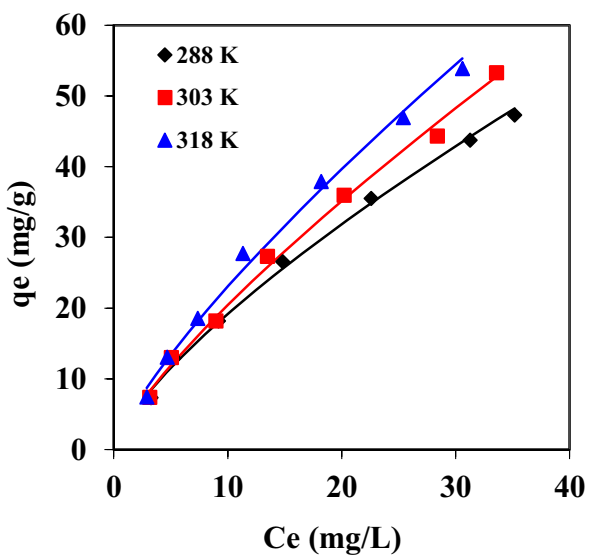

(b)

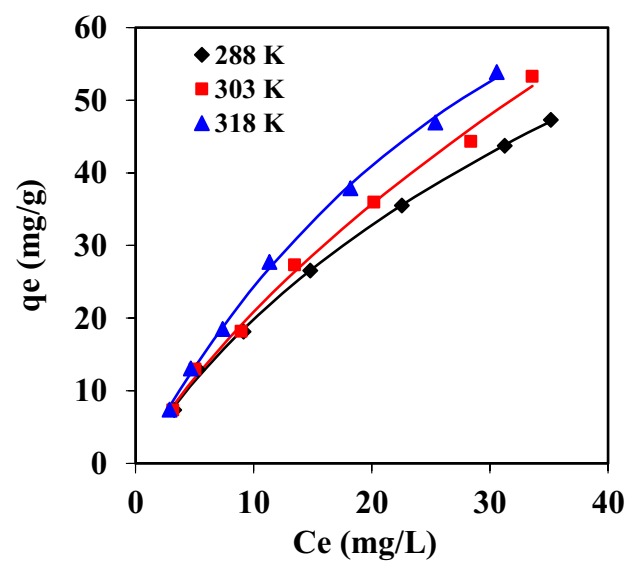

(c)

Moreover, the evaluated thermodynamics parameters for DOX-RHA adsorption are listed in Table 8 . The value of $\Delta \mathrm{H}^{\circ}$ was found as $6.226 \mathrm{~kJ} \mathrm{~mol}^{-1}$. This positive value of $\Delta \mathrm{H}^{\circ}$ demonstrates that the sorption of DOX on RHA is an endothermic physical process. The evaluated values of $\Delta \mathrm{G}^{\circ}$ were - ve, and also, this value declines with the enhancement in temperature, which specifies adsorption is spontaneous, feasible, and also enhances with the heat addition. It is visible from the parameters that, as the temperature increases, $\Delta G^{o}$ value increases, which indicates the enhancement in the sorption performance at higher temperatures. Moreover, the + ve value of $\Delta \mathrm{S}^{\circ}$ approves the enhancement in the randomness of the DOX molecules at the solid-liquid interface in the adsorption process with the increment in the temperature (Lakshmi et al. 2009). So, from the thermodynamic investigation, it is concluded that adsorption of DOX on rice husk ash is spontaneous and endothermic process.

\section{Mechanism of adsorption}

The amphoteric quality of DOX permits the presence of several ionic species at distinct ranges of $\mathrm{pH}$. The point of zero charges of RHA was evaluated as 8.1. On the other hand, DOX shows three $\mathrm{p} K$ a values $\left(\mathrm{p} K_{1}=3.5, \mathrm{p} K_{2}=7.7\right.$, $\mathrm{p} K_{3}=9.5$ ) (Gao et al. 2012). RHA has predominantly + ve charge at $\mathrm{pH}<\mathrm{pHpzc}$ and - ve charge when $\mathrm{pH}>\mathrm{pHpzc}$. At acidic $\mathrm{pH}$, the interactions between the RHA and DOX are weak due to the presence of the same charges on both compounds. Under neural conditions, the greater removal is obtained at that point because of the interactions between the $\mathrm{RHA}^{+}$and $\mathrm{DOX}^{\circ}$ forms. At this $\mathrm{pH}$, it shows that the $\mathrm{H}$-bonding and electrostatic interactions are responsible for the adsorption of DOX by RHA as shown in Fig. 7. The RHA utilized for the present study was a heterogeneous fibrous and porous structure which composed mostly of silica. The $-\mathrm{OH},-\mathrm{C}-\mathrm{OH}, \mathrm{Si}-\mathrm{O}-\mathrm{Si}$, and $\mathrm{Si}-\mathrm{H}$ groups present on the RHA surface played important role in adsorption of DOX. From FTIR, $\mathrm{O}_{2}$ in the siloxane groups on the RHA and $-\mathrm{OH}$ and amine groups of the doxycycline molecules are mainly responsible for the formation of H-bonding. On the other hand, the existence of electrostatic interactions is there amid the - $\mathrm{OH}$ and ketone groups of the DOX and silanol groups present in the RHA. 
Table 8 Isotherms and thermodynamics parameters for DOX adsorption on RHA at optimized parameters $(m=5 \mathrm{~g} / \mathrm{L}, t=85.85 \mathrm{~min}$, and $\mathrm{pH}=6)$

\begin{tabular}{|c|c|c|c|c|c|c|c|}
\hline \multicolumn{8}{|c|}{ ISOTHERMS } \\
\hline \multicolumn{3}{|c|}{ Langmuir } & \multicolumn{5}{|l|}{$q_{e}=\frac{q_{m} K_{L} C_{e}}{1+K_{L} C_{e}}$} \\
\hline $\mathrm{T}(\mathrm{K})$ & $\mathrm{K}_{\mathrm{L}}\left(\mathrm{L} \mathrm{mg}^{-1}\right)$ & & $\mathrm{q}_{\mathrm{m}}\left(\mathrm{mg} \mathrm{g}^{-1}\right)$ & & & $R^{2}$ & $\mathrm{CHI}^{2}$ \\
\hline $288 \mathrm{~K}$ & 0.036 & & 73.631 & & & 0.999 & 0.137 \\
\hline $303 \mathrm{~K}$ & 0.019 & & 128.934 & & & 0.997 & 0.321 \\
\hline $318 \mathrm{~K}$ & 0.022 & & 130.116 & & & 0.997 & 0.131 \\
\hline \multicolumn{3}{|c|}{ Redlich-Peterson } & \multicolumn{5}{|l|}{$q_{e}=\frac{K_{R} C_{e}}{1+a_{R} C_{e}^{\beta}}$} \\
\hline $\mathrm{T}(\mathrm{K})$ & $\mathrm{K}_{\mathrm{R}}\left(\mathrm{L} \mathrm{g}^{-1}\right)$ & & $\mathrm{a}_{\mathrm{R}}\left(\mathrm{L} \mathrm{mg}^{-1}\right)^{1 / \beta}$ & $\beta$ & & $R^{2}$ & $\mathrm{CHI}^{2}$ \\
\hline $288 \mathrm{~K}$ & 2.861 & & 0.077 & 0.752 & & 0.999 & 0.136 \\
\hline $303 \mathrm{~K}$ & 3.157 & & 0.133 & 0.584 & & 0.998 & 0.320 \\
\hline $318 \mathrm{~K}$ & 2.854 & & 0.012 & 1.162 & & 0.999 & 0.122 \\
\hline \multicolumn{3}{|c|}{ Freundlich } & \multicolumn{5}{|l|}{$Q_{e}=k_{f} C e^{1 / n}$} \\
\hline $\mathrm{T}(\mathrm{K})$ & & $\mathrm{K}_{\mathrm{f}}\left(\mathrm{mg} \mathrm{g}^{-1}\right)\left(\mathrm{mg} \mathrm{L}^{-1}\right)^{-1 / n}$ & $1 / \mathrm{n}$ & & $R^{2}$ & & $\mathrm{CHI}^{2}$ \\
\hline $288 \mathrm{~K}$ & & 3.541 & 0.733 & & 0.998 & & 0.307 \\
\hline $303 \mathrm{~K}$ & & 3.367 & 0.783 & & 0.997 & & 0.394 \\
\hline $318 \mathrm{~K}$ & & 3.797 & 0.783 & & 0.997 & & 0.524 \\
\hline \multicolumn{3}{|c|}{ Freundlich } & \multirow{2}{*}{\multicolumn{3}{|c|}{$\begin{aligned} \ln K_{D}=\frac{-\Delta G^{0}}{R T}= & \frac{\Delta S^{0}}{R}-\frac{\Delta H^{0}}{R} \frac{1}{T} \\
& \Delta G_{0}\left(\mathrm{~kJ} \mathrm{~mol}^{-1}\right)\end{aligned}$}} & & \\
\hline $\mathrm{T}(\mathrm{K})$ & & $K \times 10^{-3}\left(\mathrm{~L} \mathrm{~kg}^{-1}\right)$ & & & & $\Delta H_{0}\left(\mathrm{~kJ} \mathrm{~mol}^{-1}\right)$ & $\Delta S_{0}\left(\mathrm{~J} \mathrm{~mol}^{-1} \mathrm{~K}^{-1}\right)$ \\
\hline $288 \mathrm{~K}$ & & 1.985 & -18.182 & & & 6.226 & 84.519 \\
\hline $303 \mathrm{~K}$ & & 2.069 & -19.234 & & & & \\
\hline $318 \mathrm{~K}$ & & 2.544 & -20.733 & & & & \\
\hline
\end{tabular}

Fig. 7 Adsorption mechanism for DOX on RHA surface

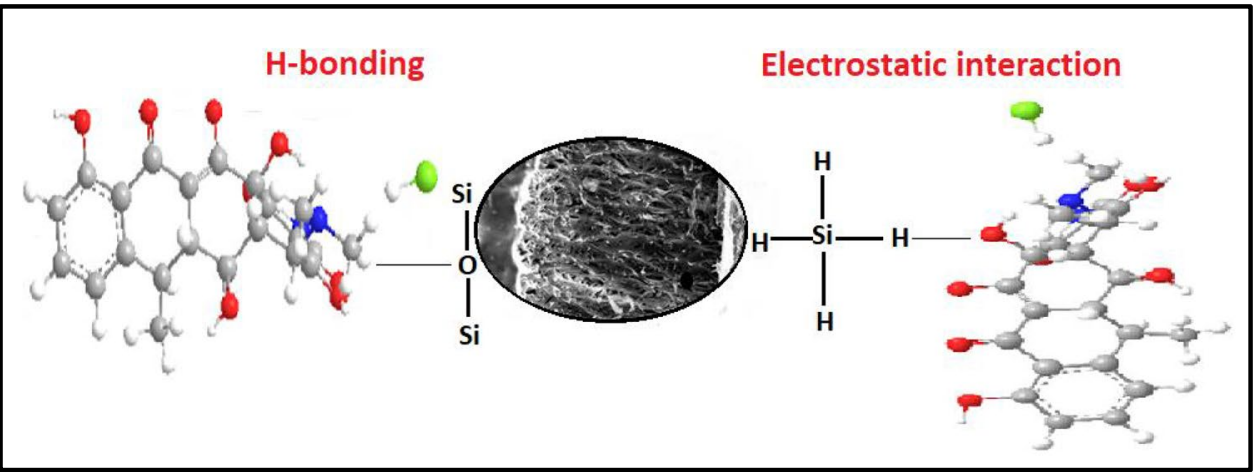

\section{Solidification/stabilization performance and toxicity test}

To ensure the safe disposal of exhausted adsorbent, it is necessary to capsulate the antibiotic present in it to avoid its further mixing in the atmosphere. Results of solidification study are shown in Fig. 8, which shows that for all the studied concentrations $(40,70$, and $100 \mathrm{mg} / \mathrm{L})$, the encapsulation percentage was $>98 \%$. The above results demonstrate that Portland cement can be used as a potential solidifying agent for almost complete encapsulation of antibiotics present in exhausted adsorbents.
The leachate was further tested to evaluate its toxicity for the possible presence of DOX into it. The comparative zone of inhibitions was observed on petri plates having EC and BC bacterial strains. From the results, it is evident that higher zones were found at $10 \mathrm{ppm}(30 \mathrm{~mm}, 28 \mathrm{~mm})$ and lower at $0.1 \mathrm{ppm}$ for EC and $1 \mathrm{ppm}$ for $\mathrm{BC}(11 \mathrm{~mm}, 14 \mathrm{~mm})$ in both cases EC and BC (Fig. 9(a and b). In Fig. 9c and $\mathrm{d}$, there were no inhibition zones seen in the growth of EC and $\mathrm{BC}$ bacterial plates. Therefore, it is indicated that $\mathrm{S} / \mathrm{S}$ process is a viable method for handling exhausted adsorbents as it could successfully capsule the antibiotic and no harmful effects against the selected bacterial strains were observed. 
Fig. $8 \%$ capsulation of DOX in cement for different adsorbent to cement mass ratios

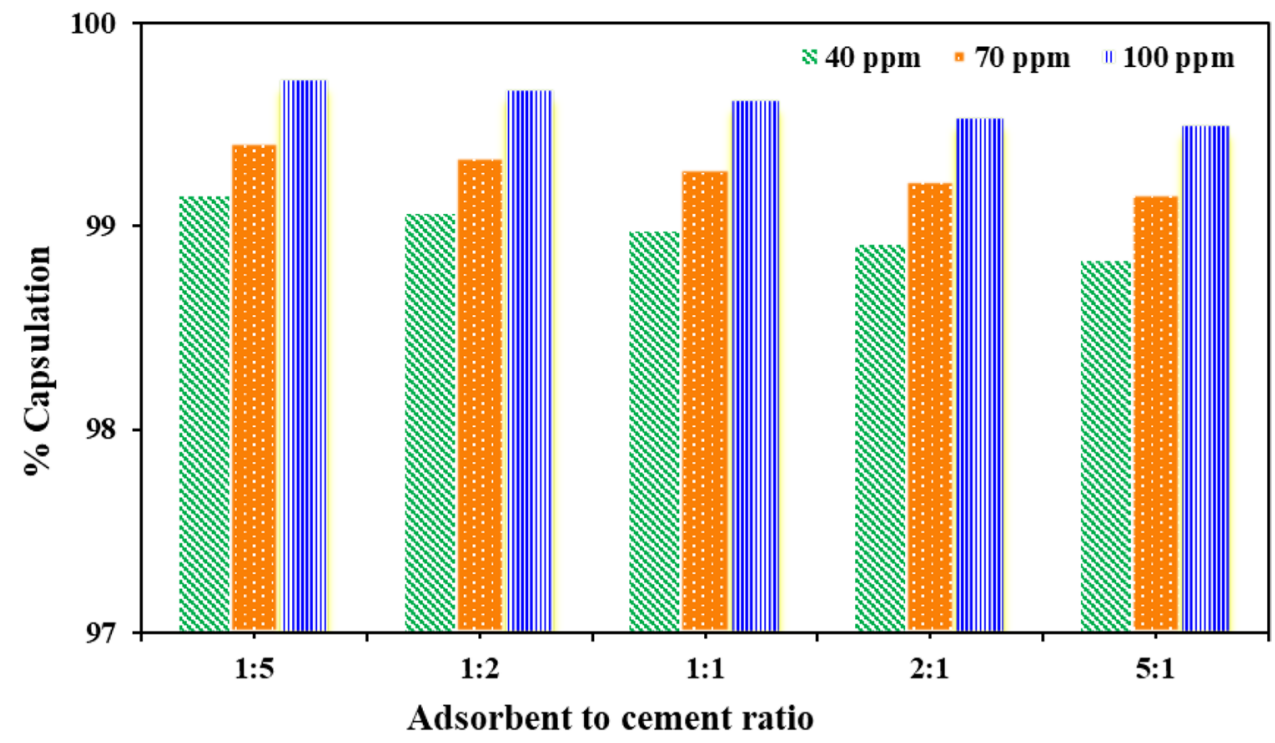

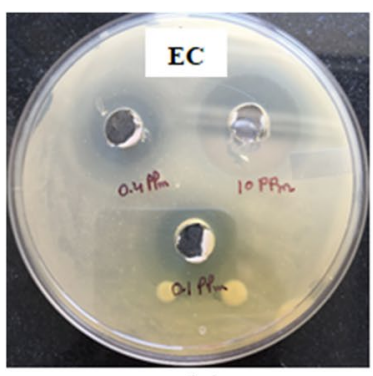

(a)

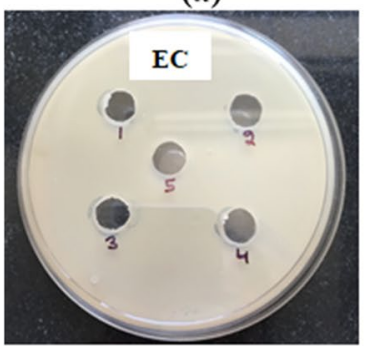

(c)

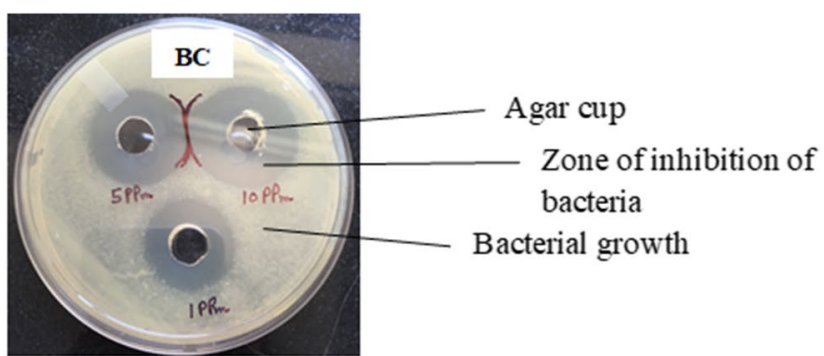

(b)

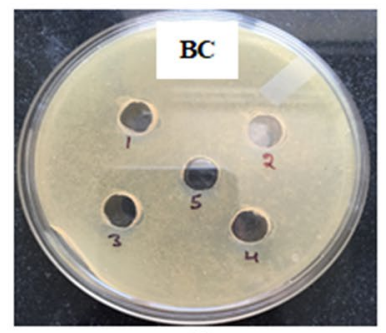

(d)

\section{Comparison of RHA with different sorbents}

The adsorptive performance of RHA was compared with few earlier used sorbents for the uptake of DOX. Table 9 represents the DOX removal percentage for previously used sorbents in comparison with RHA from aqueous solution of DOX. Very high DOX removal in case of RHA as compared to others makes it an appropriate adsorbent for DOX removal. Application of RHA as an adsorbent for removal of pharmaceutical compounds may be helpful in solving the environmental issues and at the same time it will also reduce the load of RHA generated from incinerators.

\section{Conclusion}

In the present study, RHA was established as an effectual sorbent for the adsorption of doxycycline hydrochloride from its aqueous solution. It exhibited the strong sorption capacity by giving high values for both the responses, $\mathrm{X}_{1}=98.85 \%$ and $\mathrm{X}_{2}=17.74 \mathrm{mg} / \mathrm{g}$ at optimized parameters $(m=5 \mathrm{~g} / \mathrm{L}, t=85.85 \mathrm{~min}$, DOX concentration $=89.73 \mathrm{mg} / \mathrm{L}$, and $\mathrm{pH}=6$ ). From experimental kinetic results, pseudosecond-order model fitted better than pseudo-first-order. The positive and negative values of $\Delta H^{\circ}$ and $\Delta G^{\circ}$ respectively disclosed that the uptake of DOX on RHA surface 
Table 9 Comparison of adsorptive performance of various adsorbents for DOX

\begin{tabular}{lll}
\hline Adsorbents & $\begin{array}{l}\text { Maximum \% } \\
\text { DOX removal }\end{array}$ & References \\
\hline Cobalt oxide & 66.5 & Abbas et al. 2019 \\
PSSAC & 85.82 & Kaur et al. 2021c \\
$\begin{array}{l}\text { Copper nitrate } \\
\text { modified biochar }(\mathrm{Cu}-\end{array}$ & 93.22 & Liu et al. 2017 \\
$\begin{array}{l}\text { BC) } \\
\text { DES-PSSAC }\end{array}$ & 96.30 & Kaur et al. 2021b \\
$\begin{array}{l}\text { Fe } \mathrm{O}_{4} \text { magnetic nano- } \\
\text { particles }\end{array}$ & 98.7 & Ghaemi and Absalan 2015 \\
$\begin{array}{l}\text { Rice husk biochar } \\
\text { chitosan composite }\end{array}$ & 80.23 & $\begin{array}{l}\text { Zeng et al. 2018 } \\
\text { RHA }\end{array}$ \\
\hline
\end{tabular}

is endothermic and instantaneous type by nature. Lastly, the loaded RHA fixation via the S/S method while using Portland cement as a solidifying agent resulted as an effective and safe disposal technique. Cytotoxicity assessments showed that DOX leachate sample solutions are insufficient to get rid of the aquatic flora and fauna where whole life depends and we survive. This study suggests that RHA which is an agri-residue can be a very economical and effective adsorbent for treating the pharmaceutical wastes at industrial scale. This will minimize the bio waste load and accomplish the target of "treating waste by waste."

Supplementary Information The online version contains supplementary material available at https://doi.org/10.1007/s11356-022-18961-1.

Author contribution GK: literature review and writing the original draft of the manuscript; NS and AR: critical review, expert view, and supervision of the manuscript; RKA: supervision of the manuscript. All the authors contributed to the research article and approved the final version.

Data availability Not applicable.

\section{Declarations}

Ethics approval Not applicable.

Consent to participate Not applicable.

Consent for publication Not applicable.

Conflict of interest The authors declare no competing interests.

\section{References}

Abbas RF, Hami HK, Mahdi NI (2019) Removal of doxycycline hyclate by adsorption onto cobalt oxide at three temperatures: isotherm, thermodynamic and error analysis. Int J Environ Sci Technol 16:5429-5446. https://doi.org/10.1007/s13762-018-2079-y

Abou-Mesalam MM (2003) Sorption kinetics of copper, zinc, cadmium and nickel ions on synthesized silico-antimonate ion exchanger. Colloids Surf A Physicochem Eng Asp 225:85-94. https://doi.org/ 10.1016/S0927-7757(03)00191-2

Andrade CA, Zambrano-Intriago LA, Oliveira NS, Vieira JS, QuirozFernández LS, Rodríguez-Díaz JM (2020) Adsorption Behavior and Mechanism of Oxytetracycline on Rice Husk Ash: Kinetics, Equilibrium, and Thermodynamics of the Process. Water Air Soil Pollut 231:103. https://doi.org/10.1007/s11270-020-04473-6

Bie R, Chen P, Song X, Ji X (2015) Characteristics of municipal solid waste incineration fly ash with cement solidification treatment. J Energy Inst 89:704-712. https://doi.org/10.1016/j.joei.2015.04. 006

Collier NC, Milestone NB, Hill IM, Godfrey IM (2006) The disposal of radioactive ferric floc. Waste Manage 26:769-775. https://doi. org/10.1016/j.wasman.2006.01.031

Freundlich HMF (1906) Uber die adsorption in losungen. Z Phys Chem 57:385-470. https://doi.org/10.1515/zpch-1907-5723

Gao Y, Li Y, Zhang L, Huang H, Hu J, Shah SM, Su X (2012) Adsorption and removal of tetracycline antibiotics from aqueous solution by graphene oxide. Colloid Interface Sci 368(1):540-546. https:// doi.org/10.1016/j.jcis.2011.11.015

Ghaemi M, Absalan G (2015) Fast removal and determination of doxycycline in water samples and honey by $\mathrm{Fe}_{3} \mathrm{O}_{4}$ magnetic nanoparticles. J Iran Chem Soc 12:1-7. https://doi.org/10.1007/ s13738-014-0450-6

Gupta PS, Rana MK (2020) Ivermectin, Famotidine, and Doxycycline: A Suggested Combinatorial Therapeutic for the Treatment of COVID-19. ACS Pharmacol:1037-1038.https://doi.org/10. 1021/acsptsci.0c00140

Ho YS, McKay G (1994) Pseudo-second order model for adsorption processes. Process Biochem 34:451-465. https://doi.org/10.1016/ S0032-9592(98)00112-5

Kaur R, Kushwaha JP, Singh N (2019a) Electro-catalytic oxidation of ofloxacin antibiotic in continuous reactor: evaluation, transformation products and pathway. J Electrochem Soc 166(6):H250. https://doi.org/10.1149/2.1281906jes

Kaur R, Kushwaha JP, Singh N (2019b) Electro-oxidation of amoxicillin trihydrate in continuous reactor by $\mathrm{Ti} / \mathrm{RuO}_{2}$ anode. Sci Total Environ 677:84-97. https://doi.org/10.1016/j.scitotenv.2019.04. 339

Kaur G, Singh N, Rajor A (2021a) Ofloxacin adsorptive interaction with rice husk ash: Parametric and exhausted adsorbent disposability study. J Contam Hydrol 236:103737. https://doi.org/10. 1016/j.jconhyd.2020.103737

Kaur G, Singh N, Rajor A (2021b) Efficient adsorption of doxycycline hydrochloride using deep eutectic solvent functionalized activated carbon derived from pumpkin seed shell. ChemistrySelect 6:3139-3150. https://doi.org/10.1002/slct.202100182

Kaur G, Singh N, Rajor A (2021c) Adsorption of doxycycline hydrochloride onto powdered activated carbon synthesized from pumpkin seed shell by microwave-assisted pyrolysis. Environ Technol Innov 23:101601. https://doi.org/10.1016/j.eti.2021.101601

Kaur G, Singh N, Rajor A, Kushwaha JP (2021d) Deep eutectic solvent functionalized rice husk ash for effective adsorption of ofloxacin from aqueous environment. J Contam Hydrol 242:103847. https:// doi.org/10.1016/j.jconhyd.2021.103847

Kim H, Hwang YS, Sharma VK (2014) Adsorption of antibiotics and iopromide onto single-walled and multi-walled carbon nanotubes. Chem Eng J 255:23-27. https://doi.org/10.1016/j.cej.2014.06.035

Lakshmi UR, Srivastava VC, Mall ID, Lataye DH (2009) Rice husk ash as an effective adsorbent: Evaluation of adsorptive characteristics for Indigo Carmine dye. J Environ Manage 90:710-720. https:// doi.org/10.1016/j.jenvman.2008.01.002 
Langmuir I (1918) The adsorption of gases on plane surfaces of glass, mica and platinum. J Am Chem Soc 40:1361-1403

Lataye DM, Mishra IM, Mall ID (2008) Pyridine sorption from aqueous solution by rice husk ash (RHA) and granular activated carbon (GAC): Parametric, kinetic, equilibrium and thermodynamic aspects. J Hazard Mater 154:858-870. https://doi.org/10.1016/j. jhazmat.2007.10.111

Li W, Shi Y, Gao L, Liu J, Cai Y (2013) Occurrence, distribution and potential affecting factors of antibiotics in sewage sludge of wastewater treatment plants in China. Sci Total Envir 445-446:306313. https://doi.org/10.1016/j.scitotenv.2012.12.050

Liu S, Xu W, Liu Y, Tan X, Zeng G, Li X, Liang J, Zhou Z, Yan Z, Cai X (2017) Facile synthesis of $\mathrm{Cu}(\mathrm{II})$ impregnated biochar with enhanced adsorption activity for the removal of doxycycline hydrochloride from water. Sci Total Environ 592:546-553. https:// doi.org/10.1016/j.scitotenv.2017.03.087

Mahmood T, Saddique MT, Naeem A, Westerhoff P, Mustafa S, Alum A (2011) Comparison of different methods for the point of zero charge determination of NiO. Ind Eng Chem Res 50(17):1001710023. https://doi.org/10.1021/ie200271d

Malik PK (2003) Use of activated carbons prepared from sawdust and rice-husk for adsorption of acid dyes: a case study of Acid Yellow 36. Dyes Pigm 56:239-249. https://doi.org/10.1016/S01437208(02)00159-6

Mohamed RM, Mkhalid IA, Barakat MA (2015) Rice husk ash as a renewable source for the production of zeolite $\mathrm{NaY}$ and its characterization. Arab J Chem 8(1):48-53. https://doi.org/10.1016/j. arabjc.2012.12.013

Naiya TK, Bhattacharya AK, Mandal S, Das SK (2009) The sorption of lead (II) ions on rice husk ash. J Hazard Mater 163:1254-1264. https://doi.org/10.1016/j.jhazmat.2008.07.119

Poon CS, Qiao XC, Lin ZS (2004) Effects of flue gas desulphurization sludge (FGD) on the pozzolanic reaction of reject fly ash blended cement pastes. Cem Concr Res 34:1907-1918. https://doi.org/10. 1016/j.cemconres.2004.02.027

Rahman N, Varshney P (2021) Effective removal of doxycycline from aqueous solution using $\mathrm{CuO}$ nanoparticles decorated poly (2-acrylamido-2-methyl-1-propanesulfonic acid)/chitosan. Environ Sci Pollut Res 28:43599-43617. https://doi.org/10.1007/ s11356-021-13584-4

Rani S, Garg A, Singh N (2021) Photocatalytic degradation and mineralization of amoxicillin and ofloxacin using $\mathrm{TiO}_{2}-\mathrm{SiO}_{2}$ composites. Toxicol Environ Chem 103(2):137-153

Redlich O, Peterson DL (1959) A useful adsorption isotherm. J Phys Chem 63:1024-1026

Sangal VK, Kumar V, Mishra IM (2013) Optimization of a divided wall column for the separation of C4-C6 normal paraffin mixture using Box-Behnken design. Chem Ind Chem Eng Q 19:107-119. https://doi.org/10.2298/CICEQ121019047S

Saygili H, Guzel F (2016) Effective removal of tetracycline from aqueous solution using activated carbon prepared from tomato (Lycopersicon esculentum Mill.) industrial processing waste. Ecotoxicol Environ Saf 131:22-29. https://doi.org/10.1016/j.ecoenv.2016.05. 001

Sobsey MD, Bartram S (2002) Water quality and health in the new millennium: the role of the world Health organization guidelines for drinking-water Quality. Forum Nutr 56:396-405

Srivastava VC, Mall ID, Mishra IM (2006) Characterization of mesoporous rice husk ash (RHA) and adsorption kinetics of metal ions from aqueous solution onto RHA. J Hazard Mater 134(1-3):257-67. https://doi.org/10.1016/j.jhazmat.2005.11.052

Tang WW, Zeng GM, Gong JL, Liang J, Xu P, Zhang C, Huang BB (2014) Impact of humic/fulvic acid on the removal of heavy metals from aqueous solutions using nanomaterials: a review. Sci Total Environ 468-469:1014-1027. https://doi.org/10.1016/j. scitotenv.2013.09.044

Thakur A, Sharma N, Mann A (2020) Removal of ofloxacin hydrochloride and paracetamol from aqueous solutions: Binary mixtures and competitive adsorption. Mater Today Proc 28:1514-1519. https:// doi.org/10.1016/j.matpr.2020.04.833

Weber WJ, Morris JC (1963) Kinetics of adsorption on carbon from solution. J Sanit Eng Div 89:31-59. https://doi.org/10.1061/JSEDAI.0000430

Zeng Z, Tian S, Liu Y, Tan X, Zeng G, Jiang L, Yin Z, Liu N, Liu S, Lia J (2018) Comparative study of rice husk biochars for aqueous antibiotics removal. J Chem Technol Biotechnol 93:1075-1084. https://doi.org/10.1002/jctb.5464

Zhang Z, Liu H, Wu L, Lan H, Qu J (2015) Preparation of amino$\mathrm{Fe}(\mathrm{III})$ functionalized mesoporous silica for synergistic adsorption of tetracycline and copper. Chemosphere 138:625-632. https:// doi.org/10.1016/j.chemosphere.2015.07.014

Zhang C, Lai C, Zeng G, Huang D, Yang C, Wang Y, Zhou Y, Cheng M (2016) Efficacy of carbonaceous nanocomposites for sorbing ionizable antibiotic sulfamethazine from aqueous solution. Water Res 95:103-112. https://doi.org/10.1016/j.watres.2016.03.014

Zhao Y, Gu X, Gao S, Geng J, Wang X (2012) Adsorption of tetracycline (TC) onto montmorillonite: cations and humic acid effects. Geoderma 183-184:12-18. https://doi.org/10.1016/j.geoderma. 2012.03.004

Publisher's note Springer Nature remains neutral with regard to jurisdictional claims in published maps and institutional affiliations. 